Article

\title{
The Development Perspectives of Sustainable Management Accounting in Central and Eastern European Countries
}

\author{
Beata Zyznarska-Dworczak \\ Department of Accounting, Poznan University of Economics and Business, Poznań 61-875, Poland; \\ b.zyznarska-dworczak@ue.poznan.pl; Tel.: +48-618-543-833
}

Received: 28 March 2018; Accepted: 30 April 2018; Published: 6 May 2018

check for updates

\begin{abstract}
Central and Eastern European countries undergo many political, structural, social and economic changes, with growing public awareness of the need for corporate sustainability among them. These changes influence all business activities of companies; the management accounting system, however, is particularly susceptible to the effects of these changes. Management accounting research is usually carried out using a conventional, mainstream approach, followed by most scientific researchers analyzing management accounting. This paper aims to promote the perception of the changes and prospects of the development of management accounting in Central and Eastern European countries with in-depth consideration of corporate social responsibility, viewing the role of accounting in a wider social, ethical, environmental, cultural and historical context. Therefore, the aim of this study is to contribute to the understanding of sustainable management accounting in the context of socio-economic transformations and developments in these countries, in the research perspectives of alternative management accounting. The paper relies on theoretical and methodological triangulation, using inductive and deductive reasoning as well as descriptive and comparative analysis. A bibliometric analysis, based on the scientific paper in Web of Science' database relating management accounting research in Central and Eastern Europe countries in 1945-2017, reveals key trends in changes in the field of management accounting research, and allows us to anticipate the direction of future research in this region. The results of research in these areas determine the future growth, importance, and character of the sustainable management accounting practices of companies from Central and Eastern Europe. It offers findings which are potentially useful for both theory and practice.
\end{abstract}

Keywords: accounting theory; management accounting; corporate sustainability; CSR; Central and Eastern European countries; CEECs; bibliometric analysis

\section{Introduction}

Transitional and newly industrialized or emerging economies undergo many political, structural, social and economic changes, including the growing public awareness of the need for corporate sustainability. These changes influence all business activities of companies; the management accounting system, however, is particularly susceptible to the effects of these changes. Management accounting is expected to measure economic, social and environmental performance by integrating financial information with non-financial information. Furthermore, the development of management accounting systems is also determined by a country's national culture, legislation and historical background. An analysis of the directions and factors relevant to development in the management accounting systems of Central and Eastern European countries (CEECs) (According to the classification of the OECD [1] (p. 69) the following countries are included in CEECs: Albania, Bulgaria, Croatia, the 
Czech Republic, Hungary, Poland, Romania, the Slovak Republic, Slovenia, and the three Baltic States: Estonia, Latvia and Lithuania) is valuable for a contemporary assessment of management accounting. However, a review of management accounting studies in the context of emerging economies is almost completely lacking [2] (p. 469); [3] (pp. 247-252).

Management accounting research is usually carried out using a conventional, mainstream approach, followed by most scientific researchers analyzing management accounting. Such research is characterized by functionalism and rationalism, and its purpose is to present and explain rules, meaning and the development of specific management accounting methods. This paper promotes the understanding of changes and the prospects for the development of management accounting in CEECs, with in-depth consideration of corporate sustainability by perceiving the role of accounting in a wider social, ethical, environmental, cultural and historical context. In the author's opinion this perspective can be reached via alternative approaches to management accounting.

The purpose of the paper is to contribute to the understanding of management accounting as a social activity in the context of socio-economic transformations and developments in Central and Eastern European countries, supported by the research perspectives of alternative management accounting. To the best of the author's knowledge, this study, as the first one, postulates the theoretical framework of sustainable management accounting, from the emerging economy perspective conducted in the light of alternative management accounting research. These premises allow the author to pose the following theses:

1. the analysis of the prospects of the development of management accounting in CEECs requires the perception of the role of management accounting in a wider social, ethical, environmental, cultural and historical context,

2. alternative scientific research drives the development of management accounting towards social practice, determined by the nature of the organizational and social environment, laying the foundations for an analysis of the development of sustainable management accounting in CEECs,

3. sustainable management accounting as a social practice can be a subject of alternative scientific research in the area of management accounting,

4. sustainable management accounting as a subject of alternative scientific management accounting research may constitute a means of promoting management accounting research in CEECs' companies.

To prove these theses, the paper relies on triangulation:

- theoretical-the issue at hand is identified and the encountered phenomena are described and explained by applying the precepts of alternative accounting theories (critical review of scholarly literature supported a bibliometric study), which justifies resorting to general and a-priori deduction;

- methodological—based on descriptive and comparative analysis, mixed methodological approaches in terms of deductive reasoning (theses 1-3) and inductive reasoning (thesis 4) are applied.

The data, constituting the basis of deductive reasoning in this paper, is created on the basis of the Web of Science (WoS) database. The bibliometric data covers management accounting research conducted in 1945-2017 by the authors from all countries assumed in this manuscript to be CEECs: Albania, Bulgaria, Croatia, the Czech Republic, Estonia Hungary, Latvia, Lithuania, Poland, Romania, the Slovak Republic and Slovenia. The database contains 161 publications, covering research articles, conference papers and review papers relating to management accounting in Central and Eastern European countries. The bibliometric data are collected in two databases. The first covers 1945-2017, and is a collection of the number of publications, their geographical origin, ranking of the publications by author, and also WoS categories indicating the most popular management accounting field in CEECs. It also enables us to test whether an alternative approach to management accounting has 
been adopted in the current research in CEECs so far. The second database of the bibliometric data is, in turn, source items indexed within the Web of Science Core Collection in 1998-2017, using their citation index.

The paper is structured as follows: the second section provides the background for research study, and presents a literature review concerning management accounting development in CEECs. This section presents practical justification for the study, explaining the main determinants and limitations of accounting development, as well as corporate sustainability in the face of the political, structural, social and economic transformations observed in these countries. The bibliometric analysis conducted by the author shows key trends in changes in the field of management accounting research, including those using an alternative approach, and those related to corporate sustainability. The third section, based on theoretical assumptions, gives an insight into issues regarding alternative management accounting research, its different perspectives, and factors contributing to their use in management accounting research. The fourth section presents the author's concept for the adoption of an alternative approach to management accounting research in CEECs. It reveals how an interpretive and critical approach may be the driving force in the development of management accounting in CEECs, complementing the economics-based, functionalist "mainstream". In this part, the author promotes the theoretical framework of the scope and characteristics of sustainable management accounting (SMA), indicating potential scientific management accounting research in each of the seven perspectives of alternative management accounting research. Based on the key features of SMA (indicated by the author), future research areas viewed from alternative research perspectives are set. In the author's opinion, the results of research in these areas determine the future growth, importance, and character of sustainable management accounting practices in Central and Eastern Europe.

\section{Management Accounting in Central and Eastern Europe Countries}

Central and Eastern Europe has attracted increasing attention over the last 20 years-economically, politically, and from the research standpoint. This region is still facing a lot of political, structural, social and economic transformations. Furthermore, CEECs feel the impact of such factors as global competition, the growth of internationalization, financialization, privatization, deregulation, urbanization and new technology. These changes influence all areas of business, creating a special place for the development of management accounting. Management accounting research, both in developed, as well as in developing countries, is of an eclectic and diverse nature, although it is based on uniform objectives concerning the character of social sciences and the nature of society [4] (p. 17). Contemporary research on management accounting is characterized by its interdisciplinary aspect, as well as the diversity of topics and methodologies in the analysis of mutual relationships between elements of the accounting system and its links with the organizational and social context. This implies the use of many different theories in researching management accounting systems. With positivistic, naturalistic, critical, institutional, and contextual perspectives (e.g., [2,5-13]), many management accounting scientists try to understand the multiple roles of management accounting.

Existing studies regarding management accounting in CEECs show that management accounting has become an important field of research [2,3,14-25]. However, the researchers have proved that the literature on management accounting yielded very fragmented findings, and it is difficult to generalize the results $[3,14]$. Therefore, the author of this work has applied a bibliometric method to determine state of the art research perspectives of management accounting in Central and Eastern European countries. The bibliometric study method allows the author to re-examine the question of the growth of management accounting science in this region. Due to its popular use of in the academic world, The Web of Science is selected as the key database for this study. In accordance with the assumption adopted in the introduction, the bibliometric study covers management accounting research conducted by the authors from all CEE countries: Albania, Bulgaria, Croatia, the Czech Republic, Estonia Hungary, Latvia, Lithuania, Poland, Romania, the Slovak Republic and Slovenia. In this way, a database has 
been created containing 161 publications, covering research articles, conference papers and review papers relating to management accounting in CEECs.

The first part of the bibliometric study is based on four different sets of bibliometric data from 1945-2017: the number of publications held as source items in the Web of Science (WoS, Thomson Reuters), geographical origin of management accounting research from individual CEE countries, ranking of the publications by author (Tables 1-3), and WoS categories indicating the most popular management accounting field in Central and Eastern European countries (Figure 1).

Table 1. Overview of the number of articles included in Web of Science' database relating to management accounting research of CEECs in 1945-2017.

\begin{tabular}{ccccccc}
\hline & Total & Until 2001 & 2002-2005 & 2006-2009 & 2010-2013 & 2014-2017 \\
\hline$\%$ of 161 & $100 \%$ & $0 \%$ & $3.73 \%$ & $13.04 \%$ & $32.92 \%$ & $50.31 \%$ \\
number of publications & 161 & 0 & 6 & 21 & 53 & 81 \\
\hline
\end{tabular}

Table 1 illustrates that the number of publications relating to management accounting research in Central and Eastern European countries is low, but it shows growth over the analyzed period. Additionally, most publications come from the second decade of the 21 st century, and over $50 \%$ from the last 4 years. This is due to the fact that the development of management accounting in this region, in both business practice and research, began much later, i.e., after the transition to the market economy [26] (p. 45). In developing countries, accounting has been treated for many years only via its procedural and toolbox aspect, as an information system for the needs of centralized economies. Among the challenges relating to market economy, management accounting research has been evolving to meet two demands: economic restructuring in these countries, and the dynamic development of management accounting around the world [27] (p. 22). The different strength of these factors in individual CEE countries resulted in a different level of the interest in management accounting research over the analyzed period. Each country's involvement in management accounting, calculated on the basis of the bibliometric analysis, is presented in Table 2.

Table 2. The number ranking of articles in Web of Science' database relating to the geographical origin of management accounting research in CEECs in 1945-2017.

\begin{tabular}{ccc}
\hline CEECs & Record Count & \% of $\mathbf{1 6 1}$ \\
\hline Romania & 57 & $35.404 \%$ \\
Czech Republic & 38 & $23.602 \%$ \\
Poland & 23 & $14.286 \%$ \\
Slovenia & 13 & $8.075 \%$ \\
Croatia & 8 & $4.969 \%$ \\
Hungary & 7 & $4.348 \%$ \\
Lithuania & 7 & $4.348 \%$ \\
\hline
\end{tabular}

Table 2 lists the top 7 most productive countries in management accounting research and publications. Over $34 \%$ of published management accounting papers come from Romania, almost $24 \%$-from the Czech Republic, and about 14\%—from Poland. In other CEE countries, record count share is below $10 \%$, which may indicate a very low scientific interest in management accounting issues. It may be interpreted as a niche in management accounting research, which requires a proper focus on the conditions of doing business in these countries. It may also be expected that there will be more interest in management accounting research in the future. As bibliometric analysis reveals, the papers of six scientists from the analyzed period amounts to $25 \%$ of all publications. This fragmentation of paper publication is shown in Table 3 . 
Table 3. The number ranking of the publications per author for articles in Web of Science' database relating management accounting research in CEECs in 1945-2017.

\begin{tabular}{ccc}
\hline Authors & Record Count & \% of $\mathbf{1 6 1}$ \\
\hline Dumitru & 6 & $3.727 \%$ \\
Jinga & 6 & $3.727 \%$ \\
Kral & 6 & $3.727 \%$ \\
Siska & 6 & $3.727 \%$ \\
Capusneanu & 5 & $3.106 \%$ \\
Lepadatu & 5 & $3.106 \%$ \\
Valanciene & 5 & $3.106 \%$ \\
\hline
\end{tabular}

In terms of the manuscript's purpose, the conclusion from the bibliometric analysis concerning the management accounting field in CEECs is particularly interesting. As shown in Figure 1, management accounting research uses the hypotheses of business finance, business, management, economics, educational research, metallurgy, environmental sciences, green sustainable science technology, social science and computer science. Such a multidimensional aspect is the result, to a large extent, of the use of various theories in the accounting system research. This phenomenon is in line with the a trend observable throughout the scientific world. Since the beginning of the 20th century, management accounting scientists have been interested in embarking upon research into the relationships between accounting and other scientific disciplines, including the social sciences, economics, statistics, psychology, ethics and law $[8,10,11,28-35]$. Theories which influence the final shape of the accounting system derive from various scientific disciplines and fields. The development of accounting is determined by scientific solutions, but also largely by practical needs and social expectations resulting primarily from economic, social and technological transformations.

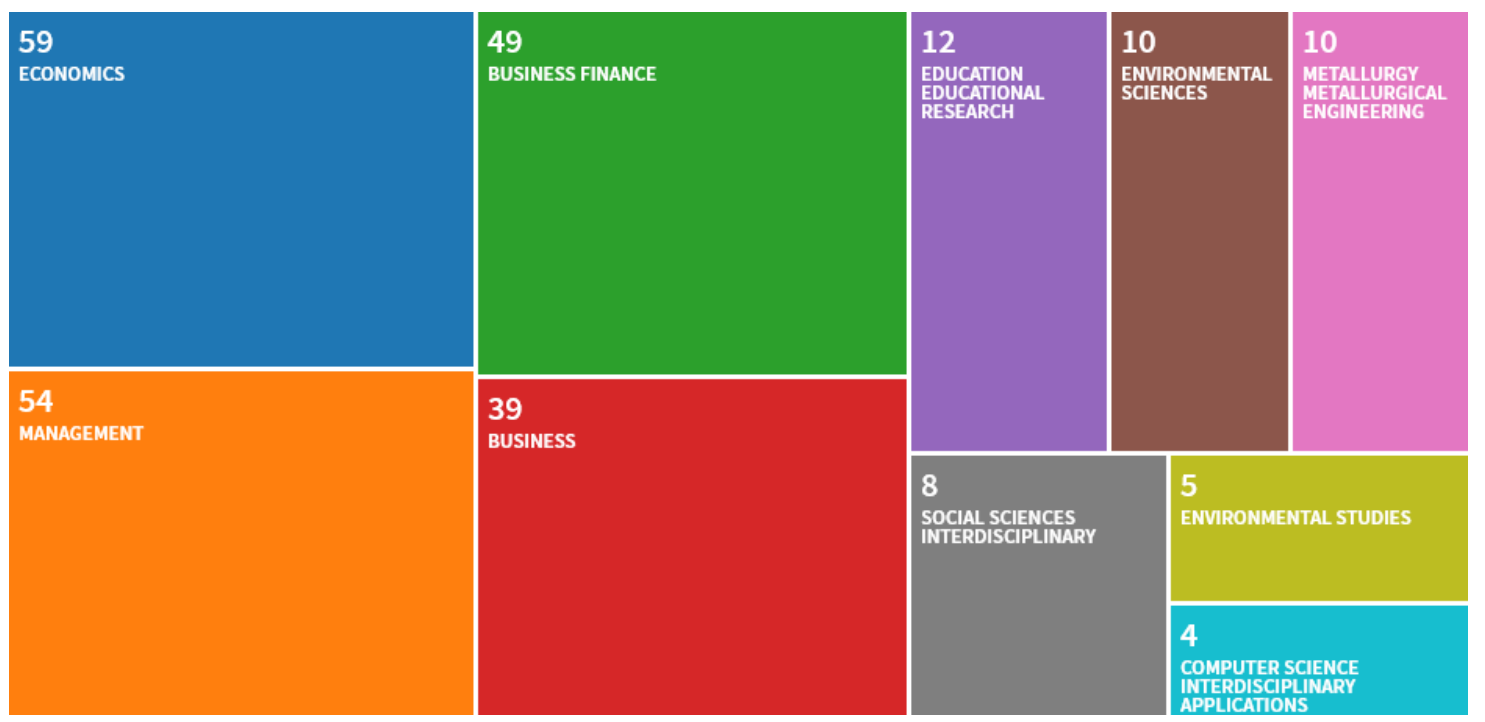

Figure 1. Web of Science Categories indicating the most popular management accounting field in CEECs in 1945-2017.

Analyzing the results of the basic management accounting research field in CEECs in 1945-2017 illustrated in Figure 1, it should be noted that some articles were concerned with more than one area. However, it may be deduced that the most popular fields are "Business Finance", "Business", "Management" and "Economics". At the same time, it is worth noting that there are two categories related to corporate sustainability as "Environmental Sciences" and "Environmental Studies", neither of which exceeds $10 \%$ of all publications. These results are in line with the results obtained by Albu and Albu [3], who state that there is a shortage of research investigating the nature and extent of CSR 
in CEECs, as compared to that of more developed countries [3] (p. 203). An investigation of CSR practices across different regions indicates that in Central and Eastern Europe, there is less tangible evidence that CSR has been high on the business agenda [36]. Historical circumstances, cultural differences, as well as institutional and economic discrepancies between CEE and more rich and developed markets, are likely to result in contrasting perspectives on the relative importance of social, economic, and environmental corporate responsibilities [37] (p. 7). Likewise, Csáfor observes that corporate sustainability has only a short past in the former socialist countries of Eastern Europe; however, a growing demand for such engagement can be noted in these states [38] (p. 115).

The concept of corporate sustainability in CEECs is relatively new, but it is rapidly gaining acceptance, in particular as part of its integration within the European Union, as well as under the influence of transnational corporations and foreign investors [39] (p. 1). The accession of Central and Eastern European countries to the European Union raised significant concerns regarding the corporate responsibility priorities in those countries. In addition, financial crises have also had a strong impact on corporate reporting in Central and Eastern European countries. They have strongly affected this region, because emerging countries are faced with a lower level of liquidity, more frequent internal and external shocks (inflation, depreciation of local currency, credit rating changes etc.), as well as a higher degree of insider trading cases [40] (p. 150). Financial crises have contributed to a loss of confidence and trust in financial institutions and other entities, which has had a significant impact on increasing the importance of transparent financial reporting, and the presentation of management approaches and their strategies in association with the implementation of the principles of sustainable development. In the face of growing interest in corporate sustainability, large undertakings in the European Union are obliged by Directive 2014/95/EU of the European Parliament to include in their management reports a non-financial statement containing information to the extent necessary for an understanding of the undertaking's development, performance, position and impact of its activity, relating to, as a minimum, environmental, social and employee matters, respect for human rights, and anti-corruption and bribery matters [41]. A growing interest in corporate sustainability in CEECs may also be the result of the membership of these countries in the United Nations. Central and Eastern European countries as member states have adopted Sustainable Development Goals (SDGs), and are expected to measure progress towards reaching the targets using many indicators. Sustainable management accounting can also be a valuable source of data for corporate responsibility reporting, supporting even SDG measurements and SDGs reporting.

The first part of the bibliometric study was completed by testing whether an alternative approach to management accounting has been adopted in the current research of CEECs so far. The Web of Science Core Collection indicates that none of the scientific papers in the Web of Science' database relating to management accounting research in this region from 1945-2017 accepted such an approach.

The second part of the bibliometric study reflects citations to source items indexed within Web of Science Core Collection in 1998-2017. Due to the fact resulting from part I. of the bibliometric test in this study - that management accounting research was not published in the years 1945-1998-the shortened period of the citation analysis in relation to the period of publication analysis does not affect comparability. The citation statistics of articles in Web of Science' database relating management accounting research in CEECs in 1998-2017 is presented in Table 4.

Table 4. Overview of the citation statistics of articles in Web of Science' database relating management accounting research of CEECs in 1998-2017.

\begin{tabular}{cc}
\hline Citation Statistics & \\
\hline Results found & 161 \\
Sum of the Times Cited & 404 \\
Average Citations per Year & 36.73 \\
Average Citations per Item & 2.51 \\
h-index & 10 \\
\hline
\end{tabular}


Table 4 indicates a relatively small response in the citations. This may be due to the small number of publications, and also partly due to the low scientific interest and awareness of the need for the management accounting development in CEECs. The ranking of the most cited articles in the Web of Science' database also indicates a low level of interest in management accounting research in CEECs over the analyzed period (see Table 5). Only one paper [42] has an average citation rate of over 10.

Table 5. The ranking of the most cited articles in Web of Science' database relating to management accounting research in CEECs in 1998-2017.

\begin{tabular}{ccccc}
\hline Publication & Authors & Publication Year & Total Citations & Average per Year \\
\hline$[42]$ & Cadez, Guilding & 2008 & 114 & 10.36 \\
\hline$[43]$ & Schaltegger, Csutora & 2012 & 63 & 9 \\
\hline$[44]$ & Staniskis, Stasiskiene & 2006 & 29 & 2.23 \\
\hline$[45]$ & Cadez, Guilding & 2012 & 20 & 2.86 \\
\hline$[3]$ & Albu, Albu & 2012 & 14 & 2.00 \\
\hline
\end{tabular}

However, based on the comparison of the cumulative citation results of management accounting development in CEECs, with the trend of their changes sum of times cited per year over the last 20 years, it may be stated that there is a growing interest in management accounting research in Central and Eastern European countries. Figure 2 shows the segmented growth of the annual number of cited references between 1998 and 2017.

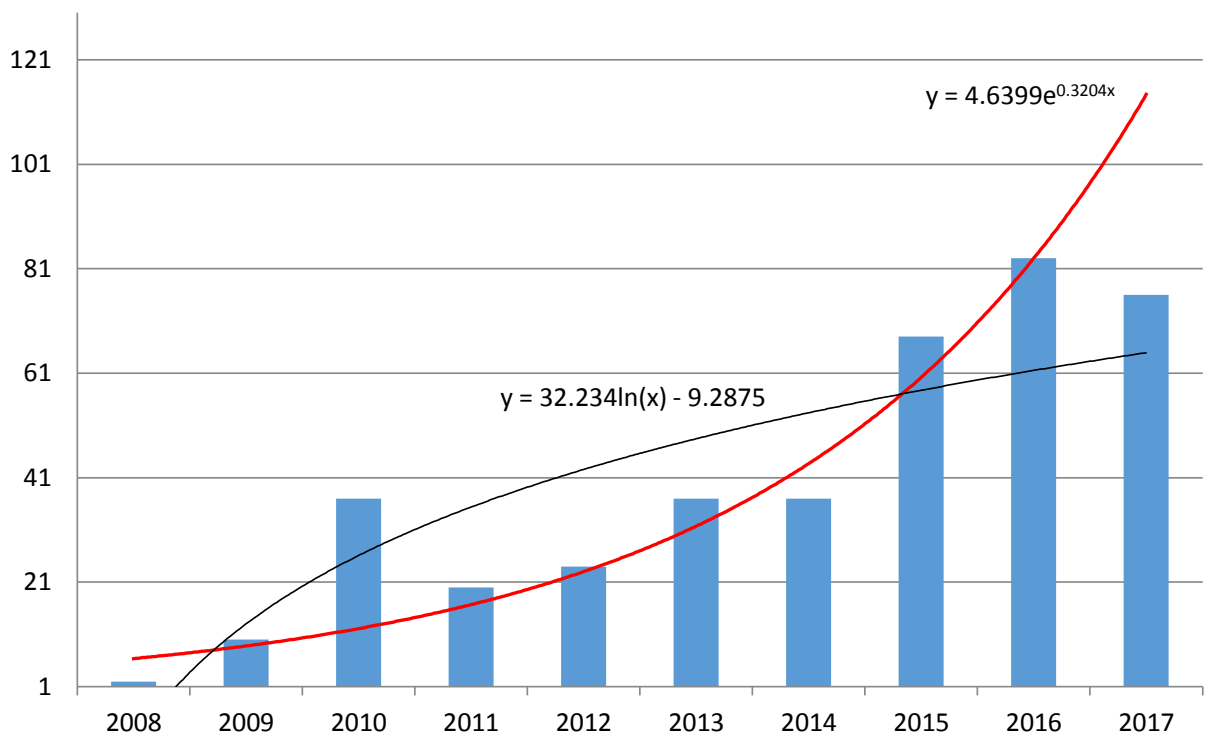

Figure 2. The growth trends of sum of times cited per year for articles in Web of Science' database relating to management accounting research in each of CEECs in 1998-2017.

As illustrated in Figure 2, the scientific interest in management accounting research in Central and Eastern European countries has been growing for over 20 years at an average rate of 80 percent per year. The trend lines in this Figure visualize the potential rates of future change in the analyzed area. The exponential trend line (red line) indicates a much more optimistic version, with a faster rate of change than the logarithmic trend line (black line). Which of these trend line will turn out to be real depends on many factors, in particular, as mentioned above, the dynamic development of management accounting around the world, as well as the difficult process of transformation in these countries. On the one hand, multinational practices generate a convergence towards a global set of management accounting practices $[19,46,47]$, which helps to raise the management accounting 
level in less developed countries. On the other hand, management accounting emerges as a highly situated phenomenon-limited by the conditions that are specific to given times and places [48] (p. 108). Therefore, to determine the pace of management accounting research development, the fact that Central and Eastern European countries are still facing a lot of political, structural, social and economic transformations must be taken into account.

Thus, for the purposes of this article, the author assumes that CEECs are a homogeneous research group for implicating the development perspectives of management accounting. In the author's opinion, business circumstances in this region are rather similar, resulting from:

- the ongoing process of socio-economic transformations and developments, which means changing the market into a capitalist economic system, changes in the form of business ownership, a changing labor market, changing capital market, changing the financial market and legislation;

- globalization and global competition, which require meeting the stakeholders' expectations regarding credibility and transparency, their CSR involvement (not only by external reporting, but also by CSR incorporation in the strategy of the entire entity), and thus gaining a comparative advantage that encourages the market to cooperate and the capital to invest;

- limited resources: capital assets, human resources (including management), intellectual capital, IT, new technology;

- increasingly strong corporate relationships with companies from Western Europe, necessitating the implementation of international policies by subsidiaries, exposing the constraints of CEECs: education, quality, know-how, technology, IT; acquisition of knowledge in the area of management accounting by enterprises in CEECs;

- facing financial crises with weaker financial and operational facilities than the rich West, in particular the weaker instrument of management in enterprises in CEECs, which is used for control and documentation, but not for governance [18];

- strong changes in their organizational structure, their production structure, managerial practices taking into account the social, environmental and ethical expectations, performance measurement, demand for more detailed information about their socio-economic and environmental potential, the need for better skills and competency of accountants;

- looking for the solutions to strengthen their management systems which will be capable of reacting to the changing internal and external environment;

- a growing need for the transformation of the sustainability of organizational practices.

In the face of the challenges relating to political, structural, social and economic transformations, together with a growing emphasis on corporate sustainability in Central and Eastern European countries, management accounting has been expected to contribute to the process of shaping the economic reality and social relationships in businesses and in society. It does mean a double challenge-addressing strategic management needs, and integrating them with a sustainable approach. Such an approach assumes that the subject matter of accounting is not only to reflect business transactions, but also to measure and evaluate their economic and social effects, also including their influence on the organizational, environmental and social relationships of a business with its internal and external environment. These tasks necessitate extending the management accounting scope to the form of sustainable management accounting - as a way of helping to pursue and harmonize a company's declared economic, environmental, social and ethical objectives, as stated in its social responsibility strategy. The trend of expanding the subject of accounting requires a complex and multifaceted accounting practice which translates significantly into the form, scope and nature of scientific research.

\section{Alternative Approach to Management Accounting Research}

Scientists have been classifying and describing research, theories, paradigms, perspectives, and research approaches in accounting for many years. Such use of multiple theories, referred to as 
"theoretical triangulation", demonstrates how advanced the science of accounting is in terms of its methodology on the one hand, while causing ambiguity on the other. This paper follows the division of research into conventional research (mainstream), relying mainly on positive theories, and alternative research (interpretative and critical), proposed by Chua [30], which generally does not use positive theories.

Conventional research, which is generally characterized by functionalism and rationalism, is considered to be dominant in management accounting research [4,19,31,34,49-52]. It is based on the objectives of neoclassical economics, operational research, and the theory of production with realistic, positivistic and deterministic perspectives. Such research results in positive theories, which are used for the presentation and explanation of the rules, meanings, and development of certain management accounting concepts and methods [9] (p. 3). This type of research has been criticized by various researchers (e.g., [53-55]), who have identified serious problems in terms of developing knowledge and innovation in the research area, impeding consideration of questions that do not methodologically fit into "positivist logic", and that cannot be expressed numerically. For these researchers, the simplification and reduction of reality via its quantification, and the formulation of hypotheses, have not contributed to a better understanding of management accounting and to predicting its development [56] (p. 174).

To address the "sterility and lacking in relevance to practical knowledge" of conventional approached to management accounting research, some researchers adopt "alternative" theoretical and methodological perspectives (c.f. $[4,5,14,55,57,58]$ ), while others are in favor of theoretical triangulation and the adoption of mixed methods research (c.f. $[8,59,60]$. Alternative researchers describe the essence of reality as something that is subjective, abstract, and complex, being a product of social and human practices; for these researchers, it is impossible to quantify and reduce reality, in contrast to what positivists believe [56] (p. 174). Based on this assumption, the alternative approach may entail expanding the basis on which management accounting is conceptualized. In this approach, management accounting can be treated as a 'system of thought' designed by humans to assist human decision-making and influence (human) behavior [9] (p. 1); this, in turn, changes the nature of accounting research which has been solidified over many years. According to Baxter and Chua [48] (p. 112), current changes in management accounting may be distinguished by their unpredictable and nonlinear-albeit socially embedded-nature. This approach, which also has been described as the interpretive approach, demonstrates the role of accounting in a wider social, ethical, environmental, cultural and historical context.

The trend of these changes is confirmed by an increasing interest among researchers in alternative approaches to management accounting research [4,5,8,11,12,30,31,48,49,61-64]. One of the main objectives of alternative management accounting research is to treat it as a social practice, which is built by a mutual influence of the external and internal environment of a business enterprise. It is pursued across scientific perspectives. The following list shows the perspectives of alternative management accounting research which are most often discussed in the literature, as identified by Baxter and Chua [48] (c.f. [65]):

1. a non-rational design school-this approach questions the assumption that decisions based on cost and benefit criteria, which are made in an organization, are rational, and it requires the management accounting system to be designed taking into account the goals and values of the entity;

2. naturalistic research-this approach assumes that management accounting practices are influenced by the complexities of the multiple constructions of the environment and the expectations that they convey; it seeks to investigate management accounting practices in their "everyday" organizational context;

3. the radical alternative-it is included in the critical approach, although it also calls for changes in business entities and in society; the main objective is to take into account the negative implications of capitalism, especially including the inequalities observed in an entity and the society, in research; 
4. institutional theory-an approach developed under the influence of the concept of institutionalism in sociology and the theory of organization; assuming limited rationality and opportunism, it helps to clarify the scope of various internal and external influences on development and changes of management accounting systems, implementation, and evaluation of the methods used to measure the achievements of various entities, including in the area of public finance; this approach is meant to show the social nature of the management accounting practice;

5. structuration theory-an approach that relates to the process of conceptualizing the interconnection between the agency of individuals (their capability to make choices) and the reproduction of social structures ("rules" and "resources"), it assigns an equal importance to the structure and the agency, and is intended to show how management accounting is connected with institutionalized social relationships, supporting the understanding of accounting as a social practice;

6. a Foucauldian approach-an approach based on the views of the French philosopher and sociologist M. Foucault concerning the relationships between knowledge, power and discourse in the context of a modern organization;

7. a Latourian approach—an approach which uses sociological actor-network theory; it shows the relationships of the parties-users accounting system from the perspective of the pursuit of their own goals.

In all types of alternative management accounting research, a qualitative research methodology is applied in contrast to the positivistic mainstream research in which quantitative research methods are used. This is because qualitative research allows for an in-depth investigation of the meaning of, and relationships between, management accounting concepts, as discussed in a specific context, e.g., organizational, institutional, historical or social. They enable researchers to take a micro-organizational perspective in scientific discovery and to take into account, in their research, acknowledged values, cultural circumstances, and people's attitudes, which form inherent parts of management accounting practices. The dominant methods in alternative research are case studies formulated from a constructivist perspective [6] (pp. 86-106), within the interpretative current, which are supplemented by interviews with members of organizations covered by a given research focus and long-term field studies.

The alternative dimension of management accounting research presented in the seven main perspectives has an interpretative and critical nature, i.e., it allows for accounting system data to be seen in a different light, taking account of the values, which give a picture under the interpretative approach or distort it under the critical approach. Alternative management accounting research can be distinguished by the approach to scientific research as a process of intellectual detection, which enables a transformation of knowledge to a more understandable form. If scientific research is treated in this way, the scope of research must be expanded, compared with the main stream, to include, among other things, the theories of organization, sociology, psychology and philosophy, as well as behavioral theories.

As demonstrated by an analysis of quantitative and qualitative research into the application of various theories in management accounting research which was conducted by Selto and Widener [66] (pp. 1-35), differences in the approach to the scope and types of other theories used in management accounting research are determined by where the researchers come from and/or where their research paper was published (geography). The authors of the research point out that, in US publications including the Journal of Accounting Research, Management Accounting Research and Advances in Management Accounting, the preferences of those researchers are clearly concentrated on scientific considerations based on economic theories, in particular the theory of agency and microeconomic theories. Sociological, psychological or organizational concepts are not used as much. On the other hand, authors from the UK consider accounting in a context wider than economics and apply interdisciplinary scientific concepts, also including those from social and behavioral sciences. Such an interdisciplinary approach is a distinguishing feature of publications in Accounting Organizations and 
Society, Advances in Management Accounting, and the Journal of Management Accounting Research. German-speaking authors, on the other hand, apply production theories and operational research, economics, strategic management, finance and capital market [13] (p. 217), [67] more than other theories in their scientific considerations.

Therefore, it can be concluded that the area of conducting research from management accounting has a significant impact upon the perspective of carrying them out. Management accounting practices are not techniques that can be abstracted from the general milieu of social development, but rather, one strand in the complex weave that makes up the social fabric [7] (p. 28). Environmental, cultural, social, ethical and historical aspects, which prompt an entity and its management to act in certain manners, potentially influence the roles and nature of management accounting. It is in this manner that a different light is shed on the role and nature of management accounting practices by the alternative research.

This is because alternative research provides a response to the practical tasks required of accounting for which science aims to create a general theoretical reference framework for the process of evaluating and formulating adequate practical solutions where management accounting plays a social role. Therefore, it may be concluded that alternative research contributes to the development of management accounting in the direction of social practice, as determined by the nature of the organizational and social environment laying the foundations for the analysis of the development of sustainable management accounting.

\section{The Author's Concept of Sustainable Management Accounting as a Subject of Alternative Management Accounting Research in CEECs (Discussion)}

This manuscript aims to present the author's concept of an adoption of alternative approach to management accounting in CEECs. The synthesis of the conclusions formulated in the empirical part of this manuscript concerning the conditions for the development and state of management accounting research in CEECs, with the conclusions formulated in the theoretical part of this manuscript concerning the possibility of extending the management accounting perspective to an alternative perspective, allows the author to postulate an adoption of an alternative approach to management accounting in Central and Eastern European countries. The innovative nature of this approach is proved by the means of bibliometric analysis, based on the database of the scientific papers in the Web of Science' database relating to management accounting research in this region from 1945-2017, as characterized in Part 2 of this manuscript. This is a new voice in the scientific discussion.

The author of the paper tries to introduce sustainable management accounting as a social and organizational activity in the context of socio-economic transformations in CEECs. As indicated in part 2 of this manuscript, Central and Eastern European countries undergo many political, structural, social, and economic changes, including a growing awareness of corporate sustainability, the need to reduce the inequalities observed in the society and business, facing financial crises, and the need to rebuild stakeholders' trust. As a key factor determining accounting systems in CEECs, there are also limited resources, primarily weaker financial and operational facilities than in the rich West, and a lower level of human and intellectual capital, IT and new technology, what motivates entities to search for non-financial methods of achieving a comparative advantage. Due to the fact that such factors are in general skipped in the economics-based mainstream approach to management accounting, the author of this manuscript promotes the extent of the management accounting research area through a transformation into a social and organizational activity, realizing a complementary role (to conventional) of this system in CEECs. This concept creates new research area focused on the development of sustainable management accounting. The author's perception of the alternative approaches to SMA research in CEECs is presented in Figure 3. 


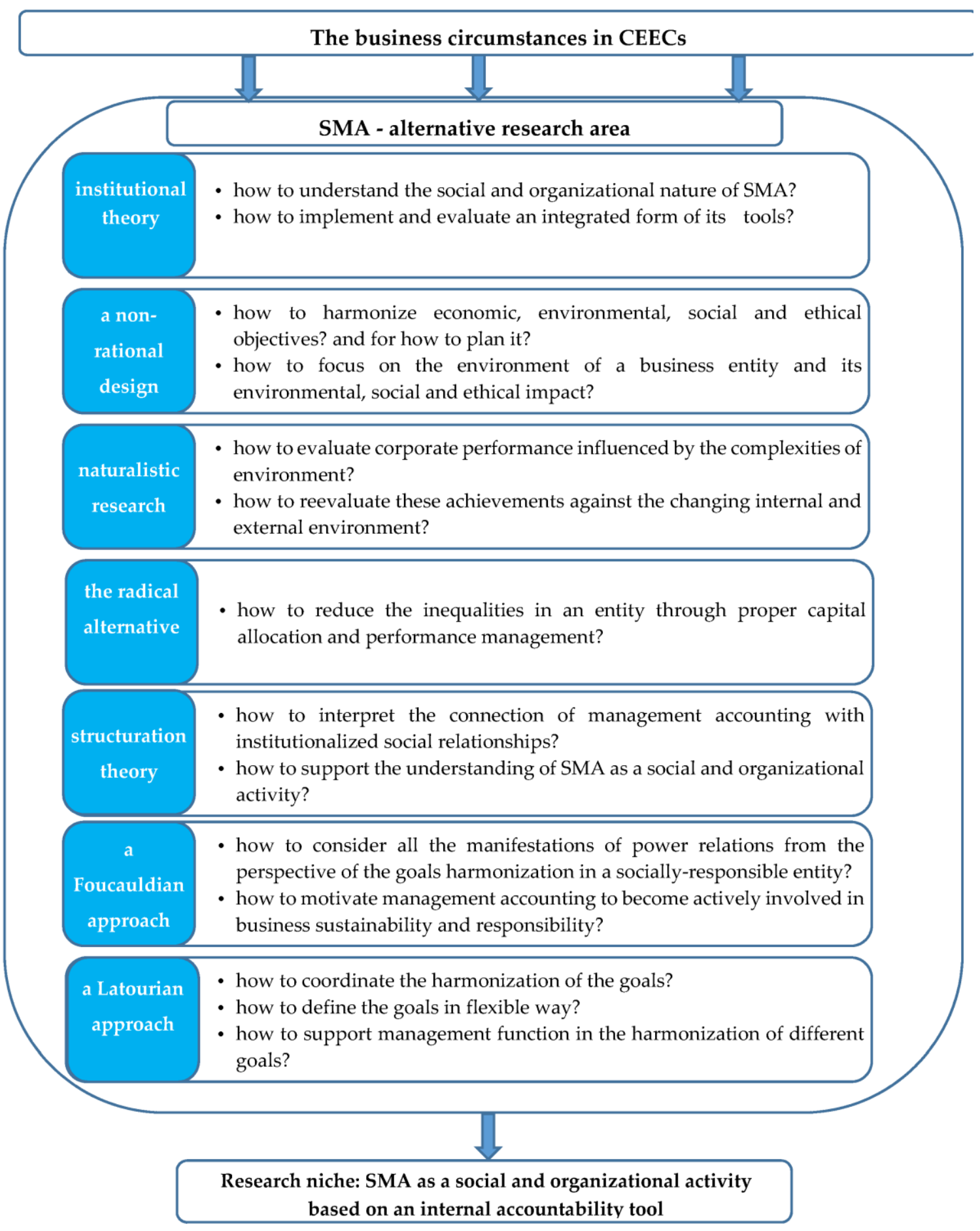

Figure 3. The author's perception of the alternative approaches to SMA research in CEECs.

In the author's opinion, each of the alternative approaches to management accounting research determines potential research questions focused on the development of sustainable management accounting. As main institutional theory assumption come from economics, sociology and political science, this theory provides the widest perspective of SMA perception as a social and organizational activity. Its limited rationality helps management accounting researcher to explain the miscellaneous internal and external influences on an entity's environment, as well as to evaluate the methods to measure them. Furthermore, as Figure 3 reveals, a non-rational design school and naturalistic research 
may help researchers to conduct their scientific investigation in the perspective of the expected in CEECs' companies harmonization of economic, environmental, social and ethical objectives and their measurement. Therefore, these approaches may also constitute a way of management accounting research concentrated on an entity's environment and its environmental, social and ethical impact, against the changing internal and external environment. These relationships may also be perceived from the radical alternative approach. In particular, this approach may help to understand the role of SMA focused on a reduction of the inequalities observed in the society and business, resulting from the strength of economic categories. The radical alternative perspective may provoke researchers to reflect more deeply upon how to measure corporate socio-environmental potential to increase its importance on the background of economic results.

The understanding of accounting as a social and organizational practice may also be explained according to the assumption of structuration theory. As is presented in Figure 3, this alternative approach may support researchers in interpreting the connection of management accounting with institutionalized social relationships. A Foucauldian approach, in turn, is expected to find the answers to the research question: how to consider all the manifestations of power relations in a socially-responsible entity, expected to harmonize its different goals. This approach may also give rise to research on the possibilities of motivating management accounting to become actively involved in business sustainability. However, this research area requires in-depth investigation relating the coordination of an entity's team in achieving the harmonization of the goals. A complement to the answer to this research question may be a response given by a Latourian approach, which may help to research the role of management function in the harmonization of economic, environmental, social and ethical goals.

To fill the revealed in Figure 3 research niche resulting from the perception of SMA as a social and organizational, the author of this manuscript, as the first, postulates the theoretical framework of sustainable management accounting from the emerging economy perspective conducted in the light of alternative management accounting research. The scope and key characteristics of SMA, in turn, allow the author to indicate the prospects and the determinants of the development of sustainable management accounting in Central and Eastern European countries. The author's concept of SMA in the light of alternative management accounting research potential is presented in Table 6 .

Table 6. Author's concept of SMA in the light of alternative management accounting research potential.

\begin{tabular}{|c|c|c|}
\hline Characteristics & Sustainable Management Accounting & Research Areas and Alternative Research Perspective \\
\hline Importance/goal & $\begin{array}{l}\text { Balance between the economic, social, } \\
\text { environmental and ethical goals }\end{array}$ & $\begin{array}{l}\text { - The strategic role of SMA in socially responsible } \\
\text { businesses-from the institutional } \\
\text { theory perspective; } \\
\text { - Decision to switch from a rational maximization } \\
\text { of business value/profit to the harmonization of } \\
\text { goals within the current of alternative } \\
\text { research-a non-rational design school and a } \\
\text { naturalistic research }\end{array}$ \\
\hline How goals are defined & Flexibility in defining goals & $\begin{array}{l}\text { - Research in the Foucauldian } \\
\text { approach perspective }\end{array}$ \\
\hline Stakeholders & $\begin{array}{l}\text { Basically internal, supporting } \\
\text { sustainability reporting also external }\end{array}$ & $\begin{array}{l}\text { - Research in the Foucauldian } \\
\text { approach perspective }\end{array}$ \\
\hline Relationships with the environment & $\begin{array}{l}\text { Focus on the environment of a } \\
\text { business entity and its environmental, } \\
\text { social and ethical impact }\end{array}$ & $\begin{array}{l}\text { - Development of qualitative research focused on } \\
\text { the integration of quantitative results with } \\
\text { qualitative results and value results; } \\
\text { - SMA is used to communicate the actual } \\
\text { outcomes of social responsibility strategy to } \\
\text { members of the internal and } \\
\text { external environment; } \\
\text { - Research from the perspective of the radical } \\
\text { alternative, structuration theory and } \\
\text { institutional theory }\end{array}$ \\
\hline
\end{tabular}


Table 6. Cont.

\begin{tabular}{|c|c|c|}
\hline Characteristics & Sustainable Management Accounting & Research Areas and Alternative Research Perspective \\
\hline The form & $\begin{array}{l}\text { An integrated form of planning and } \\
\text { control methods and tools for the } \\
\text { fulfillment of economic, social and } \\
\text { environmental goals supporting the } \\
\text { evaluation of the business entity's } \\
\text { impact on its environment }\end{array}$ & $\begin{array}{l}\text { - Construction of an account of the responsibility } \\
\text { for business activities carried out for } \\
\text { sustainable development; } \\
\text { - Integration of financial and non-financial } \\
\text { information within the Foucauldian } \\
\text { approach perspective }\end{array}$ \\
\hline Instruments & $\begin{array}{l}\text { Activity Based Responsibility } \\
\text { Accounting, Sustainable BSC, Activity- } \\
\text { and Strategy-Based Responsibility } \\
\text { Accounting }\end{array}$ & $\begin{array}{l}\text { - Development of SMA tools to conduct the } \\
\text { responsibility account; } \\
\text { - } \quad \text { Development of qualitative SMA research tools; } \\
\text { Development of tools to integrate financial and } \\
\text { non-financial information in order to measure } \\
\text { the economic, social and environmental } \\
\text { potential, and to anticipate its changes in the } \\
\text { long run; } \\
\text { - } \quad \text { Research in the institutional theory perspective } \\
\text { - } \quad \text { Research in the Foucauldian } \\
\text { approach perspective }\end{array}$ \\
\hline Achievement measurement indicators & $\begin{array}{l}\text { Financial and non-financial indicators: } \\
\text { - } \quad \text { economic, } \\
\text { - } \quad \text { environmental (natural } \\
\text { environmental), } \\
\text { - } \quad \text { labor, } \\
\text { - } \quad \text { social engagement, } \\
\text { - } \quad \text { other }\end{array}$ & $\begin{array}{l}\text { - Further additional work, GRI indicators used } \\
\text { in practice; } \\
\text { - Analysis of the possibilities of deducing from an } \\
\text { integration of qualitative and quantitative } \\
\text { results, disclosed in financial or } \\
\text { non-financial terms }\end{array}$ \\
\hline $\begin{array}{l}\text { Participation of various management } \\
\text { levels in planning and control }\end{array}$ & $\begin{array}{l}\text { Group decision-making, including } \\
\text { lower level personnel, making it } \\
\text { possible to take multiple business } \\
\text { impact perspectives into account }\end{array}$ & $\begin{array}{l}\text { - Using SMA to communicate the actual } \\
\text { outcomes of the social responsibility strategy to } \\
\text { personnel at various levels in the organization; } \\
\text { - Analyzing the use of management and } \\
\text { organization theory with respect to the } \\
\text { possibilities to coordinate teams from } \\
\text { different departments; } \\
\text { - Research in the Foucauldian } \\
\text { approach perspective }\end{array}$ \\
\hline
\end{tabular}

As indicated in Table 5, the author assumes that the main goal of SMA is to achieve a balance between the economic, social, environmental, and ethical goals in socially-responsible businesses. In this sense, SMA may be treated as a tool of sustainability control system that a socially-responsible entity develops for its own needs, and adapts to its own social responsibility policy objectives. Sustainable management accounting is focused on the environment of a business entity and its environmental, social and ethical impact. These aspects of accounting are understood in the manuscript in this way that management accounting is "regarded as a social and institutional practice, one that is intrinsic to, and constitutive of, social relations, rather than derivative or secondary" [68] (p. 1). This, in turn, entitles the author to treat accounting as a system of mutual relationships with the organizational, natural and social environment, supported by the bilateral impact a socially-responsible entity and its stakeholders and shareholders. Thus it may help to understand and explain the 
importance of management accounting of an entity harmonizing the fulfillment of economic, social and environmental goals.

The concept of SMA research requires a consideration of the widest relationships of an entity to its environment, and its impacts in the longest period possible when measuring achievements. Therefore, the author's concept focuses on interpretative and critical research requiring an expansion of the current quantitative research, so that it includes qualitative research. It allows the inclusion of non-financial information in the management accounting system, which is generally skipped in the mainstream approach. This perspective in management accounting research forces the creation of "new calculable spaces" [69] by the means of new management accounting techniques, distinguished-as Baxter and Chua suggested [48]—by "flexibility", "modernity", "worldclass" and "quality". Such a multidimensional measurement of achievements poses a particular challenge to SMA research. It requires the construction of the SMA system in an integrated form of methods and tools allowing planning and control of the fulfillment of economic, social and environmental goals. What can be helpful is a responsibility account which holds managers accountable for the effects of their business entity's sustainable development activities. Such an account must be supported by instruments which integrate financial and non-financial information, including Activity Based Responsibility Accounting, Sustainable Balanced Scorecard, and Activity- and Strategy-Based Responsibility Accounting (e.g., [70-76]). Before these tools can be applied, more in-depth research into institutional theory perspective is required regarding the possibilities of designing and using such tools to measure the economic, social and environmental potential of a socially responsible business, and to anticipate how it is going to change in the long run. Such research may derive its strength from a combination of quantitative and qualitative research methods, since they require the integration of quantitative and qualitative data from various perspectives from which business goals are perceived using a properly selected set of economic, environmental, labor and social engagement indicators.

This manuscript assumes that SMA creates an internal accountability tool, allowing for the calculation and management of financial and non-financial indicators: economic, environmental, labor, social and other. Nevertheless the creation of high quality accounting data supporting internal decision-making may also support corporate sustainability and SDGs reporting. It extends the management accounting research area into many new potential research issues relating to the SMA utility for sustainability reporting from internal and external stakeholders perspective, and an integration of reporting functions into internal management decision-making. Furthermore, due to the fact that "sustainability reporting is becoming an organization-wide process that continuously informs and involves many key internal decision-makers" [77], research into sustainability reporting from a management accounting perspective may also open up new research opportunities in management accounting.

In the author's opinion, this defined scope of SMA forces management accounting researchers to conduct their research primarily in the institutional theory perspective into the social role of SMA and its strategic role in socially-responsible businesses. They are also expected to adopt-even partly-a non-rational design school, which involves abandoning the rational business value/profit maximization approach. Thus, valuable area of management accounting research is the phenomenon of how an organizational and social context moves management accounting systems towards the cognitive and cultural explanations of an entity. At the same time it is worth examining how these aspects empower the management accounting system to perform stabilizing and standardizing functions within an entity. The key research assumption may be perceiving management accounting as a tool to legitimize these management decisions, which may harmonize sustainable development goals, taking into account enabling financial conditions and organizational effectiveness. Researchers adopting these alternative approaches may, in a non-conventional way, understand the form of sustainable management accounting influenced by the complexities of the entity's environment and the expectations that they convey. 
What may be particularly valuable to SMA development is the research into the role of accounting in the process where a business entity builds relationships with, and influences, its environment. Such research may be supported by qualitative research focused on integrating quantitative results with qualitative and value results relating to sustainable development actions. The radical alternative, structuration theory, and institutional theory approaches which are helpful in such research, target the measurement of a socially responsible entity's achievements, taking into account the social, organizational and behavioral relationships in the longest time horizon possible. Adopting an Latourian approach in management accounting research may, in turn, help to understand stakeholders' information needs, and determine what kind of data the SMA should provide, and thus, the direction in which the management is supposed to act.

Research on how the management function is performed may significantly contribute to the further development of sustainable management accounting. Although the primary purpose of SMA is the multidimensional measurement of results, the possibility of communicating them has a considerable effect on the possibilities of performing the other functions of managing a socially responsible business, such as planning, controlling and organizing the fulfillment of its social responsibility policy objectives. The Latourian approach perspective may, in contrast, significantly assist management accounting researchers in the application of SMA to motivate personnel across the organization to respect social responsibility policy objectives, including sociological techniques.

Research into the participation of various levels of management in planning and controlling results will allow analyses of the possibilities of group decision-making, which will permit a number of perspectives on how a business entity impacts its environment to be considered. The Foucauldian approach, using organization and management theories, is dedicated to research into team coordination and flexibility of defining goals. It suggests a means of motivating management accounting to become actively involved in business responsibility, and may be used for internal management decision-making, including financial and nonfinancial transactions that affect the external and internal environment of the business.

Finally, the management model in companies in Central and Eastern European countries may be supported by the sustainable management accounting system, fulfilling the users' needs, both internally and externally. This direction of management accounting development requires a lot of in-depth research. The distinguishing feature of sustainable management accounting research is its multidimensional nature, since it requires integrating various perspectives of planning and evaluating the fulfillment of social responsibility strategy objectives, taking into account, in particular, its bilateral impact on the external and internal environment of the business. What poses a particular challenge to the researchers is the use of quantitative and qualitative research to create a general theoretical framework for measuring the financial and non-financial achievements of a socially responsible business. The results of the research in these areas determine the future growth, importance and character of sustainable management accounting practice in Central and Eastern European countries.

\section{Conclusions}

The paper demonstrates that the multidimensional and interdisciplinary nature of management accounting research enables development of sustainable management accounting by the transformation into a social and institutional activity, realizing a complementary role (to conventional) of the management accounting system in Central and Eastern European countries. It promotes the extent of the management accounting research area relating to the ways in which management accounting helps a socially-responsible entity to influence a multiplicity of stakeholders and shareholders, and in turn, how it is influenced by them. Thus, the reasoning provided in this paper confirmed the theses put forward herein, and demonstrated that the main objective has been achieved. It was shown that the mutual fusion and interaction of theories in management accounting research gives rise to its multidimensional and interdisciplinary nature. Because of the chosen research approach and the gap in the literature of the analyzed area, the research results may lack generalizability. The study, 
although responding to the needs of the practice, is theoretical in nature. Therefore, the conclusions from the research will be soon filled by in-depth empirical research relating to the changes in the management accounting system, conducted in companies operating in Poland. Nevertheless, the author of this manuscript postulates the theoretical framework of SMA from the emerging economy perspective conducted in the light of alternative management accounting research. This framework is to constitute the potential for further research into sustainable management accounting and its development opportunities in companies from this region.

The paper demonstrates that key features enable the development of management accounting in the direction of a social practice, determined by the nature of the organizational and social environment, thus making it a subject of alternative research. The characteristics of the alternative approach to management accounting research, as shown in this paper, allows one to conclude that sustainable management accounting may be a subject of alternative management accounting research. Therefore, the author's concept of SMA research reveals that each of the alternative approaches to management accounting research determines the potential of future research of sustainable management accounting. However, institutional theory is of special importance, because its assumptions enable accounting to play a significant role in establishing the very social structure of a socially-responsible entity, and it may consequently be considered as a social and organizational activity. As indicated in this paper, alternative approaches may also make a significant contribution to the development of sustainable management accounting; they may support management accounting researchers in finding the way of the expected in CEECs' companies harmonization of economic, environmental, social and ethical objectives and their measurement. They may motivate us to measure corporate socio-environmental potential, to increase its importance on the basis of economic results. Such research will be focused on integrating quantitative results with qualitative and value results, relating to sustainable development actions taking into account the social, organizational and behavioral relationships over the longest possible time frame. As suggested in the manuscript, such research will concern the measurement of the achievement of economic, social, environmental and ethical goals of a socially responsible business, taking into account, in particular, its impact on the external and internal environment, based on a social responsibility account relying on integrated financial and non-financial information. Furthermore, the results of sustainable management accounting research within the alternative school may significantly contribute to a better understanding of an interpretation of the connection of management accounting with institutionalized social relationships due to structuration theory, as well as of a consideration of all the manifestations of power relations in a socially-responsible entity due to a Foucauldian approach. Therefore, the alternative approaches contribute in synergic way to recognizing the social nature of management accounting practice in companies, as expected by market participants.

The development of further sustainable management accounting research is determined by the results of research in those areas, especially with regards to the possibilities of using quantitative and qualitative research to devise general theoretical frameworks for measuring achievements in a socially responsible business, based on the account of responsibility. Management accounting around the world embraces a new direction in the form of an SMA, which, in CEECs, has a specific justification within the context of socio-economic transformations and developments.

Acknowledgments: This paper has been written as part of the project No. 51102-2-96 entitled "The quality of corporate reporting - new challenges and the prospect of change". The project is carried out by the Poznan University of Economics and Business.

Conflicts of Interest: The author declares no conflict of interest.

\section{References}

1. Organisation for Economic Co-operation and Development. Agricultural Policies in OECD Countries: Monitoring and Evaluation; OECD: Paris, France, 2003.

2. Hopper, T.; Tsamenyi, M.; Uddin, S.; Wickramasinghe, D. Management accounting in less developed countries: What is known and needs knowing. Account. Audit. Account. J. 2009, 22, 469-514. [CrossRef] 
3. Albu, N.; Albu, C.N. Factors associated with the adoption and use of management accounting techniques in developing countries: The case of Romania. J. Int. Financ. Manag. Account. 2012, 23, 245-276. [CrossRef]

4. Wanderley, C.; Cullen, J. Management accounting research: Mainstream versus alternative approaches. Contab. Vista Revist. 2011, 22, 15-44.

5. Chua, W.F. Interpretive sociology and management accounting research-A critical review. Account. Audit. Account. J. 1988, 1, 59-79. [CrossRef]

6. Humphrey, C.; Scapens, R.W. Methodological themes: Theories and case studies of organizational accounting practices: Limitation or liberation? Account. Audit. Account. J. 1996, 9, 86-106. [CrossRef]

7. Covaleski, M.A.; Dirsmith, M.W.; Samuel, S. Managerial accounting research: The contributions of organizational and sociological theories. J. Manag. Account. Res. 1996, 8, 1-35.

8. Gaffikin, M. The Critique of Accounting Theory; Working Papers 25; School of Accounting \& Finance, University of Wollongong: Wollongong, Australia, 2006. Available online: http:/ / ro.uow.edu.au/accfinwp/41 (accessed on 10 January 2018).

9. Hoque, Z. Introduction. In Methodological Issues in Accounting Research: Theories, Methods and Issues; Hoque, Z., Ed.; Spiramus Press Ltd.: London, UK, 2006.

10. Kakkuri-Knuuttila, M.-L.; Lukka, K.; Kuorikoski, J. Straddling between paradigms: A naturalistic philosophical case study on interpretive research in management accounting. Account. Organ. Soc. 2008, 33, 267-291. [CrossRef]

11. Parker, L.D. Interpreting interpretive accounting research. Crit. Perspect. Account. 2008, 19, 909-914. [CrossRef]

12. Arroyo, P. Management accounting change and sustainability: An institutional approach. J. Account. Organ. Chang. 2012, 8, 286-309. [CrossRef]

13. Szychta, A. Kierunki alternatywnych badań naukowych w rachunkowości zarządczej (Directions of alternative management accounting research). Zesz. Teor. Rachun. 2014, 80, 193-223. [CrossRef]

14. Jaruga, A.; Ho, S.S.M. Management accounting in transitional economies. Manag. Account. Res. 2002, 13, 375-378. [CrossRef]

15. Haldma, T.; Lääts, K. Contingencies influencing the management accounting practices of Estonian manufacturing companies. Manag. Account. Res. 2002, 13, 379-400. [CrossRef]

16. Alawattage, C.; Hopper, T.; Wickramasinghe, D. Introduction to management accounting in less developed countries. J. Account. Organ. Chang. 2007, 3, 183-191. [CrossRef]

17. Mayr, S. Management accounting in Eastern Europe: Cultural influence and empirical evidence from Slovakia. Int. J. Bus. Res. 2012, 12, 161-169.

18. Shields, M.D. Management accounting practices in Europe: A perspective from the States. Manag. Account. Res. 1998, 9, 501-513. [CrossRef]

19. Mathews, M.R. Twenty-five years of social and environmental accounting research: Is there a silver jubilee to celebrate? Account. Audit. Account. J. 1997, 10, 481-531. [CrossRef]

20. Gray, R.H. The social accounting project and accounting, organizations and society: Privileging engagement, imaginings, new accountings and pragmatism over critique? Account. Organ. Soc. 2002, 27, 687-708. [CrossRef]

21. De Palma, R.; Csutora, M. Productivity, viability and improved environmental performance. In Introducing Environmental Management Accounting (EMA), at Enterprise Level Methodology and Case Studies from Central and Eastern Europe; UNIDO United Nations Industrial Development Organization: Vienna, Austria, 2003.

22. Bennett, M.; Bouma, J.J.; Wolters, T. The Development of Environmental Management Accounting: General Introduction and Critical Review. In Environmental Management Accounting: Informational and Institutional Developments; Bennett, M.D., Bouma, J.J., Wolters, T.J., Eds.; Science \& Business Media: Dordrecht, The Netherlands; Boston, MA, USA; London, UK, 2006.

23. Zyznarska-Dworczak, B. System rachunkowości zarządczej w dobie społecznej odpowiedzialności przedsiębiorstw/Management accounting system in the era of corporate social responsibility. Stud. Oecon. Posnan. 2014, 5, 142-156.

24. Gutierrez-Huerter, G.O.; Gold, S.; Moon, J.; Chapple, W. Transfer of Social and Environmental Accounting and Reporting Knowledge: Subsidiary Absorptive Capacity and Organisational Mechanisms. In Perspectives on Headquarters-Subsidiary Relationships in the Contemporary MNC; Ambos, T.C., Ambos, B., Birkinshaw, J., Eds.; Research in Global Strategic Management; Emerald Group Publishing Limited: Bingley, UK, 2016; Volume 17, pp. 299-328. [CrossRef] 
25. Vamosi, T.S. Continuity and change; management accounting during processes of transition. Manag. Account. Res 2000, 11, 27-63. [CrossRef]

26. Almasan, A.; Circa, C.; Zarzycka, E.; Dobroszek, J. Management accounting information from the perspective of managers: The case of Poland and Romania. Selected findings of a survey research. Zesz. Teor. Rachun. 2016, 146, 41-46. [CrossRef]

27. Szychta, A. European Traditions in Accounting: Cost and Management Accounting in Poland; The Official Newsletter of the European Accounting Association: Aalto, Finland, 2013; Volume 42, pp. 19-23. Available online: http:/ / www.eaa-online.org/userfiles/file/EAA-Newsletter-Nr42--2013(1).pdf (accessed on 10 January 2018).

28. Llewelyn, S. What counts as theory in qualitative management and accounting research? Introducing five levels of theorizing. Account. Audit. Account. J. 2003, 16, 662-708. [CrossRef]

29. Colville, I. Reconstructing "Behavioural Accounting”. Account. Organ. Soc. 1981, 6, 119-132. [CrossRef]

30. Chua, W.F. Radical developments in accounting thought. Account. Rev. 1986, LXI, 601-665.

31. Kasanen, E.; Lukka, K.; Siitonen, A. The constructive approach in management accounting research. J. Manag. Account. Res. 1993, 5, 243-264.

32. Malmi, T.; Granlund, M. In Search of management accounting theory. Eur. Account. Rev. 2009, 18, 597-620. [CrossRef]

33. Nikolaou, I.E.; Evangelinos, K.I. Classifying current social responsibility accounting methods for assisting a dialogue between business and society. Soc. Responsib. J. 2010, 6, 562-579. [CrossRef]

34. Van der Meer-Kooistra, J.; Vosselman, E. Research paradigms, theoretical pluralism and the practical relevance of management accounting knowledge. Q. Res. Account. Manag. 2012, 9, 245-264. [CrossRef]

35. Dunk, A.S. Behavioral Research in management accounting: The past, present, and future. Adv. Account. Behav. Res. 2015, 5, 25-45. [CrossRef]

36. Furrer, O.; Egri, C.; Ralston, D.; Danis, W.M.; Reynaud, E.; Naoumova, I.; Molteni, M.; Starkus, A.; Darder, F.L.; Dabic, M.; et al. Attitudes Toward Corporate Responsibilities in Western Europe and in Central and East Europe. Manag. Int. Rev. 2010, 50, 379-398. [CrossRef]

37. Fijałkowska, J.; Zyznarska-Dworczak, B.; Garsztka, P. Corporate Social-Environmental Performance versus Financial Performance of Banks in Central and Eastern European Countries. Sustainability 2018, 10, 772. [CrossRef]

38. Csáfor, H. Corporate social responsibility in Central and Eastern Europe. Period. Oecon. Stud. Econ. Sci. Region. Dev. Compet. 2008, 115-127. Available online: http://www.gti.ektf.hu/anyagok/po/2008/PO2008_ CsaforH.pdf (accessed on 10 April 2018).

39. Habek, P. CSR Reporting Practices in Visegrad Group Countries and the Quality of Disclosure. Sustainability 2017, 9, 2322. [CrossRef]

40. Živković, S.; Aktan, B. Global financial crisis and VaR performance in emerging markets: A case of EU candidate states-Turkey and Croaia. J. Econ. Bus. 2009, 27, 149-170.

41. Directive 2014/95/EU of the European Parliament and of the Council of 22 October 2014 amending Directive 2013/34/EU as regards disclosure of non-financial and diversity information by certain large undertakings and groups (Text with EEA relevance). In Official Journal of the European Union L 330 of 15.11.2014; European Parliament, Council of the European Union: Brussels, Belgium, 2014.

42. Cadez, S.; Guilding, C. An exploratory investigation of an integrated contingency model of strategic management accounting. Account. Organ. Soc. 2008, 33, 836-863. [CrossRef]

43. Schaltegger, S.; Csutora, M. Carbon accounting for sustainability and management. Status quo and challenges. J. Clean. Prod. 2012, 36, 1-16. [CrossRef]

44. Staniskis, J.K.; Stasiskiene, Z. Environmental management accounting in Lithuania: Exploratory study of current practices, opportunities and strategic intents. J. Clean. Prod. 2006, 14, 1252-1261. [CrossRef]

45. Cadez, S.; Guilding, C. Strategy, strategic management accounting and performance: A configurational analysis. Ind. Manag. Data Syst. 2012, 112, 484-501. [CrossRef]

46. Bouwens, J.; Abernethy, M.A. The consequences of customization on management accounting system design. Account. Organ. Soc. 2000, 25, 221-241. [CrossRef]

47. Granlund, M.; Lukka, K. It's a small world of management accounting practices. J. Manag. Account. Res. 1998, 10, 153-179. 
48. Baxter, J.; Chua, W.F. Alternative management accounting research-Whence and whither. Account. Organ. Soc. 2003, 28, 97-126. [CrossRef]

49. Baker, C.R.; Bettner, M.S. Interpretive and critical research in accounting: A commentary on its absence from mainstream accounting research. Crit. Perspect. Account. 1997, 8, 293-310. [CrossRef]

50. Wagenhofer, A. Management accounting research in German-speaking countries. J. Manag. Account. Res. 2006, 18, 1-19. [CrossRef]

51. Baxter, J.; Boedker, C. The future(s) of interpretive accounting research-A polyphonic response from beyond the metropolis. Crit. Perspect. Account. 2008, 19, 880-886. [CrossRef]

52. Zyznarska-Dworczak, B. Zrównoważona rachunkowość zarządcza w świetle teorii legitymizacji/Sustainable management accounting in the light of the legitimacy theory. Zesz. Teor. Rachun. 2015, 82, 181-190. [CrossRef]

53. Scapens, R.W. Never mind the gap: Towards an institutional perspective on management accounting practice. Manag. Account. Res. 1994, 5, 301-321. [CrossRef]

54. Williams, P.F. The myth of rigorous accounting research. Account. Horiz. 2014, 28, 869-887. [CrossRef]

55. Hopper, T.; Bui, B. Has management accounting research been critical? Manag. Account. Res. 2016, 31, 10-30. [CrossRef]

56. Major, M.J. Positivism and "alternative" accounting research. Revista Contabilidade Financ. 2017, 28 , $173-178$. [CrossRef]

57. Roslender, R.; Dillard, J.F. Reflections on the interdisciplinary perspectives on accounting project. Crit. Perspect. Account. 2003, 14, 325-351. [CrossRef]

58. Parker, L.D. Qualitative management accounting research: Assessing deliverables and relevance. Crit. Perspect. Account. 2012, 23, 54-70. [CrossRef]

59. Lillis, A.M.; Mundy, J. Cross-sectional field studies in management accounting research-Closing the gaps between surveys and case studies. J. Manag. Account. Res. 2005, 17, 119-141. [CrossRef]

60. Anderson, S.W.; Widener, S.K. Doing quantitative field research in management accounting. In Handbooks of Management Accounting Research; Chapman, C.S., Hopwood, A.G., Shields, M.D., Eds.; Elsevier: Oxford, UK, 2006; Volume 1, pp. 319-341.

61. Lukka, K. The roles and effects of paradigms in accounting research. Manag. Account. Res. 2010, $21,110-115$. [CrossRef]

62. Tomkins, C.; Groves, R. The everyday accountant and researching his reality. Account. Organ. Soc. 1983, 8, 361-374. [CrossRef]

63. Laughlin, R. Empirical research in accounting: Alternative approaches and a case for middle-range thinking. Account. Audit. Account. J. 1995, 8, 63-68. [CrossRef]

64. Ahrens, T. Overcoming the subjective-objective divide in interpretive management accounting research. Account. Organ. Soc. 2008, 33, 292-297. [CrossRef]

65. Zyznarska-Dworczak, B. Zrównoważone zarządzanie kosztami wobec alternatywnych badań naukowych w rachunkowości zarządczej. Prace Naukowe Uniwersytetu Ekonomicznego we Wrocławiu 2015, 398, 500-508. [CrossRef]

66. Selto, F.H.; Widener, S.K. New directions in management accounting research: Insights from practice. Adv. Manag. Account. 2004, 12, 1-35.

67. Hopper, T.; Otley, D.; Scapens, R. British management accounting research: Whence and whither: Opinions and recollections. Br. Account. Rev. 2001, 33, 263-291. [CrossRef]

68. Miller, P. Accounting as Social and Institutional Practice: An Introduction; Hopwood, A.G., Miller, P., Eds.; Accounting as Social and Institutional Practice; Cambridge University Press: Cambridge, UK, 1994.

69. Miller, P.; O'Leary's, P. Accounting expertise and the politics of the product: Economic citizenship and modes of corporate governance. Account. Organ. Soc. 1993, 18, 187-206. [CrossRef]

70. Hörisch, J.; Ortas, E.; Schaltegger, S.; Álvarez, I. Environmental effects of sustainability management tools: An empirical analysis of large companies. Ecol. Econ. 2015, 120, 241-249. [CrossRef]

71. Falle, S.; Rauter, R.; Engert, S.; Baumgartner, R.J. Sustainability Management with the Sustainability Balanced Scorecard in SMEs: Findings from an Austrian Case Study. Sustainability 2016, 8, 545. [CrossRef]

72. Lu, I.-Y.; Kuo, T.; Lin, T.-S.; Tzeng, G.-H.; Huang, S.-L. Multicriteria Decision Analysis to Develop Effective Sustainable Development Strategies for Enhancing Competitive Advantages: Case of the TFT-LCD Industry in Taiwan. Sustainability 2016, 8, 646. [CrossRef] 
73. Maas, K.; Schaltegger, S.; Crutzen, N. Integrating corporate sustainability assessment, management accounting, control and reporting. J. Clean. Prod. 2016, 136, 237-248. [CrossRef]

74. Pérez, C.Á.; Montequín, V.R.; Fernández, F.O.; Balsera, J.V. Integrating Analytic Hierarchy Process (AHP) and Balanced Scorecard (BSC) Framework for Sustainable Business in a Software Factory in the Financial Sector. Sustainability 2017, 9, 486. [CrossRef]

75. Rodríguez-Olalla, A.; Avilés-Palacios, C. Integrating Sustainability in Organisations: An Activity-Based Sustainability Model. Sustainability 2017, 9, 1072. [CrossRef]

76. Pérez, C.Á.; Montequín, V.R.; Fernández, F.O.; Balsera, J.V. Integration of Balanced Scorecard (BSC), Strategy Map, and Fuzzy Analytic Hierarchy Process (FAHP) for a Sustainability Business Framework: A Case Study of a Spanish Software Factory in the Financial Sector. Sustainability 2017, 9, 527. [CrossRef]

77. Soderstrom, K.M.; Soderstrom, N.S.; Stewart, C.R. Sustainability/CSR Research in Management Accounting: A Review of the Literature; Malina, M.A., Ed.; Advances in Management Accounting; Emerald Publishing Limited: Bingley, UK, 2017; Volume 28, pp. 59-85.

(C) 2018 by the author. Licensee MDPI, Basel, Switzerland. This article is an open access article distributed under the terms and conditions of the Creative Commons Attribution (CC BY) license (http:/ / creativecommons.org/licenses/by/4.0/). 